\title{
Effect of Pesticides on Enzymatic Activity in Soil
}

\author{
Maria-Mihaela MICUȚI ${ }^{1}$, Liliana BĂDULESCU ${ }^{1}$, Florentina ISRAEL-ROMING ${ }^{1}$ \\ ${ }^{1}$ University of Agronomic Sciences and Veterinary Medicine of Bucharest, 59Marasti Blvd, \\ District 1, Bucharest, Romania \\ *corresponding author: mihaela.micuti@yahoo.com
}

Bulletin UASVM Animal Science and Biotechnologies 75(2)/ 2018

Print ISSN 1843-5262; Electronic ISSN 1843-536X

DOI:10.15835/buasvmcn-asb: 2017.0040

\begin{abstract}
The focus of this article is to provide informations about soil enzymatic activity as a biological indicator for impacts of pesticides on soils. In this experiment, an ecological soil was treated with two types of fungicide (Ridomil Gold and Bravo 500) and two of insecticides (Mospilan 20SG and Vertimec 1.8\% EC). The pesticides were assessed for their effect on different enzymatic activities. They were administrated over a 28 days period and the samples of soil were taken once every 7 days and analyzed in the laboratory. For each sample was determined the enzymatic activity, pH, humidity. The enzymatic activity was assessed using colorimetrical methods. Enzymes chosen for this study were cellulase, amylase, xylanase, urease, alkaline and acid phosphatase. Results shown that the enzymatic activity can increase or decrease when the soil was treated with the fungicides and insecticides chosen for this experiment.
\end{abstract}

Keywords: enzymes, fungicides, insecticides, soil quality

\section{INTRODUCTION}

Nowadays, a major problem that arises in modern agriculture is the excessive use of various pesticides (fungicides, herbicides and insecticides) to effectively control a variety of pests. One of the negative effects of applying pesticides is the formation of pesticide residues in the soil, concluding with the immersion of these xenobiotic compounds. Another negative effect of pesticides use is that they can destroy or suppress not only the target organisms in agricultural crops, but also can affect non-target organisms which are responsible for increasing the soil fertility (Anuradha et al. 2015). However, there are researches that demonstrated that pesticides are capable to stimulate soil enzymes. Singh and Kumar (2008) demonstrated that acetamipirid enhanced the activity of dehydrogenases, whereas Baćmaga et al. (2012) reported the stimulatory effect of carfentrazone-ethyl on acid phosphatase and alkaline phosphatase. Once pesticides have reached the soil they can be degradated by various processes as hydrolysis, ionization, evaporation, oxidation, photolysis, and microbiological decomposition. The microbiological decomposition is the most efficient process in transforming harmful chemical substances because certain microbial species and strains can become tolerant to chemicals by developing defense mechanisms (Katayama et al. 2010).

Presence of enzymes in soil is closely related to fertility and soil biological equilibrum but also with the changes that occur in biological status due to pollution (Chu et al. 2003, Bending et al. 2004). Soil enzyme activities are sensitive indicators of soil quality because they respond quickly to either environmental stress or management practice changes (Sravanthi et al. 2015).

The aim of this study was to assess the potential of soil enzyme as indicators of soil contamination. Four pesticides commonly used in Romania, Ridomil Gold MZ 68WG, Bravo 500 SC, Mospilan 20SG and Vertimec 1.8 \% EC, were used to highlight the influence of them on soil enzymatic activity. Enzymes chosen for study are important due to their critical role in C (cellulase, 
amylase, xylanase), $\mathrm{N}$ (urease), $\mathrm{P}$ (acid and alkaline phosphatase) cycles and nutrient mineralization processes.

\section{MATERIALS AND METHODS}

\section{Soil and pesticide characteristics}

In the experiment was used an ecological soil mixed with perlite and peat, taken from ecological department from Research Centre for the Quality Study of Food Products greenhouse. The soil was collected from a 0-20 cm depth.

Pesticides selected for the present investigation were two fungicides (Ridomil Gold MZ 68WG and Bravo $500 \mathrm{SC}$ ) and two insecticides (Mospilan 20SG and Vertimec 1.8 \% EC). Ridomil Gold MZ 68WG (RG) has systemic and contact action due to the active substance metalaxyl-M $4 \%$ and mancozeb 68\%. Bravo $500 \mathrm{SC}$ (BV) is a contact fungicide containing chlorothalonil $500 \mathrm{~g} \mathrm{/} \mathrm{L.}$ Mospilan 20SG- Acetamiprid $200 \mathrm{~g} / \mathrm{kg}$ (MO) is a systemic insecticide from the neonicotinoid product group, with a broad spectrum of control. Vertimec $1.8 \%$ (VE) is acaricide-insecticide to combat pest damage in vegetable crops, with a translaminar activity. The active ingredient of that second insecticide is abamectin.

\section{Experimental design}

The ecological soil collected from the greenhouse was put in 17 pots of $10 \mathrm{~cm}$ diameter and kept in the greenhouse throughout the experiment. Four aqueous solutions of pesticides were prepared according to commercial formulations. Each of them were sprayed in $10 \mathrm{~mL}$ doses once every 7 days over a 28 days period on the ecological soil. Soil without pesticides was used as a control sample (day 0). Soil sampling was made at a $0-15 \mathrm{~cm}$ depth, once every 7 days, before pesticide treatment. The soil samples were kept in the refrigerator at $4 \mathrm{C}$ prior to analysis in order to have a constant humidity.

\section{Enzyme assays}

The soil samples at 7, 14, 21, 28 days were subjected to several enzymes assay, such as: cellulase, amylase, xylanase, urease, alkaline and acid phosphatase. For the determination of cellulase activity in soil was used $1 \%$ carboxymethyl cellulose (CMC) as a substrate in acetate buffer $\mathrm{pH}=5.5$ and incubated $24 \mathrm{~h}$ at $50^{\circ} \mathrm{C}$ (Deng and Tabatabai, 1994). The colorimetrical reaction was carried out using 3,5-Dinitrosalicylic acid reagent (DNS). Xylanase activity was deter- mined according to the DNS assay for quantification of enzymatically released reducing sugars, using as substrate xylan (Miller,1959). The method for the amylase assay was determined by the method proposed by Colle (1977) and adopted by Tu (1982). The $\alpha$ - amylase activity was measured using a colorimetric method with 3,5-dinitrosalicylic acid (DNS) reagent, having $2 \%$ starch as a substrate. The quantity of the formed ammonia was determined by colorimeter with Nessler's reagent, after soil incubation 2 $\mathrm{h}$ at $37 \mathrm{C}$ with urea and TRIS buffer (Tabatabai and Bremner, 1972). Phosphatase activity was determined with a colorimetric method which involves the use of an artificial substrate (p-nitrophenilphosphate) (Tabatabaiand Bremner, 1969). The pNPP was hydrolysed to $p$-nitrophenol (pNP) and determined spectrophotometrically at $400 \mathrm{~nm}$.

For each soil sample taken at the four points of administration of the four pesticides, besides the enzymatic activity, were determined the $\mathrm{pH}$ and the dry substance. Soil pH was determined using a $\mathrm{pH}$ meter, with glass electrode, $\mathrm{pH}$ range $0-14 \pm 1$ and soil-water ration in the range of $1: 10$. For the dry matter determination was used a thermobalance.

\section{Statistical analysis}

Data were analyzed using one-way ANOVA and the Fisher's least significant difference (LSD) were calculated using Post Hoc Test in Microsoft Excel.

\section{RESULTS AND DISCUSSIONS}

\section{Effect of fungicides interactions on} enzymes activity

Cellulase is a very important enzyme involved in the decomposition of soil organic matter. According to the figure $1 \mathrm{a}$, the application of Ridomil Gold fungicide led to a extremely significant stimulation of cellulase activity from day 7 to day 21 ( $\mathrm{P} \leq 0.001)$. The same results were reported by Ramudu et al. (2011) who observed that after pesticide administration cellulase activity was significantly enhanced.

For xylanase, soil treatment with fungicides leads to a slight increase in enzymatic activity, but it was't noticed any significant statistical differences towards control (Figure 1c). Regarding amylase activity it can be observed that Ridomil Gold fungicide had lead to a significant $(\mathrm{P} \leq 0.05)$ 


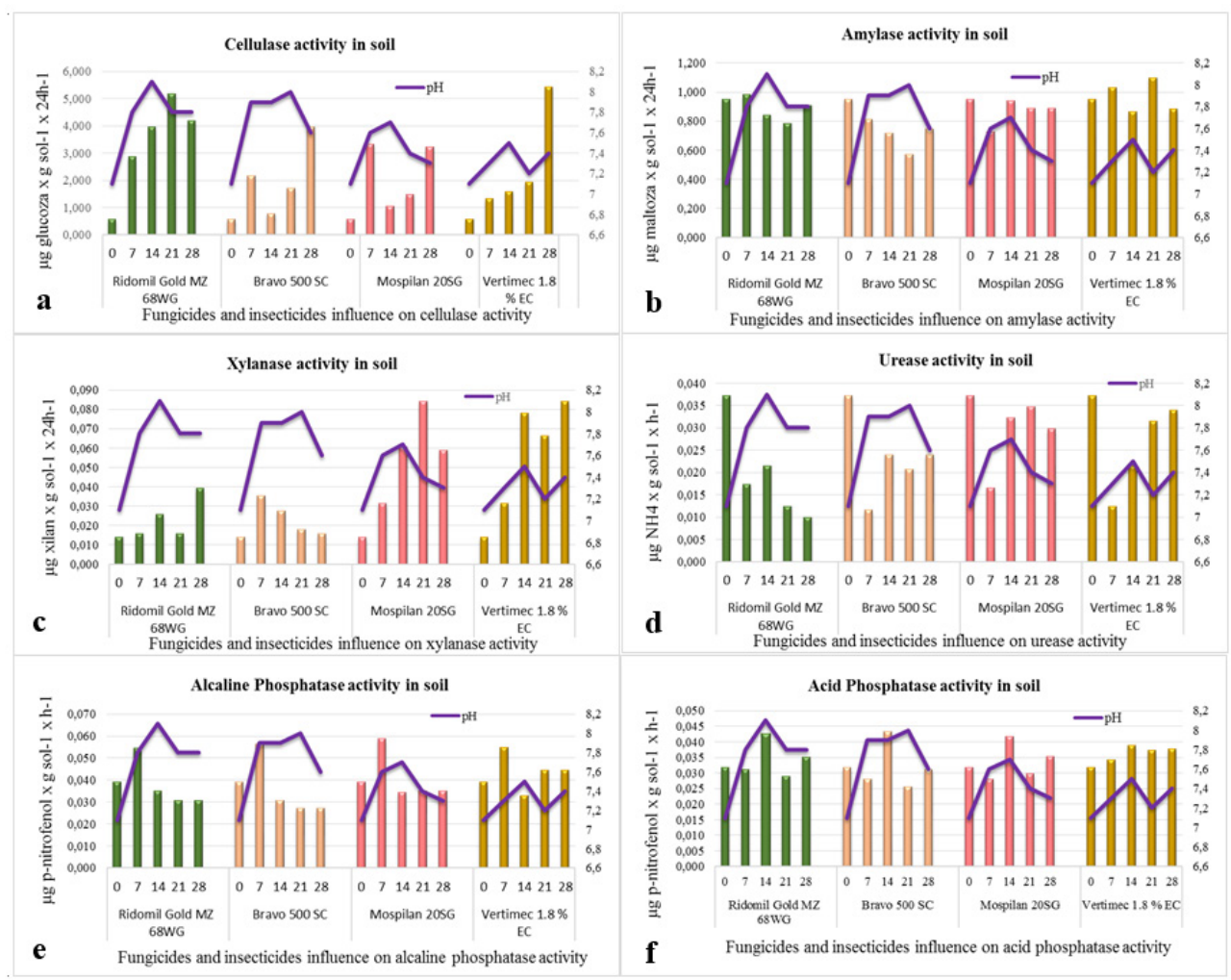

Figure 1. Soil enzymes activity after pesticides applications (cellulase, amylase, xylanase, urease, alkaline and acid phosphatase) correlated with soil $\mathrm{pH}$.

decrease of enzymatic activity (Figure 1b). Bravo $500 \mathrm{SC}$ had a very significant influence on amylase activity $(\mathrm{P} \leq 0.01)$. There are positive correlation between the influence of the two fungicides on the enzymatic activity ( $\mathrm{r}=0.857)$. Madhuri (2014) reported that amylase enzyme activity was not affected by the selected fungicides when they were applied at recommended application rate.

Urease activity was influenced after the first treatment for both fungicides. Ridomil Gold had a highly significant effect on the urease activity ( $\mathrm{P} \leq$ 0.001 ) compared with the control. It was noticed a very significant effect $(P \leq 0.01)$ on urease activity after soil treatment with Bravo 500 SC fungicide. From figure $1 \mathrm{~d}$ can be observed that the both fungicides had a similar influence on soil urease activity exerting an decrease. Urease activity decreased with $73 \%$ after RG application and with 35\% after BV application. This observation is in concordance with several works which reported that fungicides appear to have strongly inhibited the activity of urease (Bagmaga, 2016). After the four treatments with each fungicide wasn't observed any significant modifications of alkaline and acid phosphatase activities compared to untreated soil. Most of referenced studies reported that various fungicide application on soil may stimulate or have no effect on the acid phosphatase activity (Monkiedje et al. 2002, Yan et al. 2011).

Effect of insecticide interactions on enzymes activity

Gundi et al. (2007) pointed out that insecticides have a globally stimulating effect, because the molecules of insecticides destroy the soil insects and form substrates available for

stimulation of cellulase activity. According to the figure 1a the two insecticides (Mospilan 20SG and Vertimec $1.8 \%$ EC) stimulated considerable the cellulase activity $(\mathrm{P} \leq 0.05)$ during the four treatments $(7,14,21,28$ days).

The same increase in activity can be observed in the case of xylanases (Figure 1c), both insecticides having a very significant influence on xylanase activity $(\mathrm{P} \leq 0.01)$. The activity of amylase in soil slightly decreased, in comparison with the control ( 0 days), $25 \%$ after mospilan treatment and $7 \%$ when was treated with 
vertimec until the last day of treatment (Figure $1 b)$. These changes are not statisticaly significant different from control. Changes in amylase activity were reported also by Ismail (1998). His results were shown that insecticides caused a reduction in amylase activity especially at 28 days of incubation. Urease activity marked a decrease after first treatment ( 7 days) but later the activity started to increase (Figure 1d). Throughout the study, Vertimec showed a significant influence on urease activity compared with control $(\mathrm{P} \leq 0.05)$. The decrease in urease activity can be due to the ability of microorganisms to develop defense mechanisms against the action of the Vertimec insecticide active ingredient (Katayama et al. 2010). Alkalin and acid phosphatase responded differently after the insecticides application. Indeed, using the same insecticide may stimulate alkaline phospatase and inhibit acid phospatase and vice versa (Defo et al. 2011, Jastrzebska 2011). Regarding to insecticides, alkaline and acid phosphatase activity is considerably modified only after Vertimec insecticide application $(\mathrm{P} \leq 0.01)$. In the case of alkaline phosphatase the modifications are insignificant (Figure 1e).

In addition, a positive correlation can be observed between the $\mathrm{pH}$ and the influence of Vertimec insecticide on acid phosphatase activity ( $\mathrm{r}=0.808$ ). Ridomil Gold had also a positive correlation with the $\mathrm{pH}$ regarding the influence on cellulase activity ( $\mathrm{r}=0.819)$.

\section{CONCLUSION}

Enzyme activity modifications may be attributed to the structure of microbial consortium and its sensibility to certain pesticides treatment. In short time experiments, several researchers demonstrated that pesticides show positive, negative or no effect on the activities of enzymes in soils.

The results obtained in the present study clearly indicate that the fungicide Ridomil Gold profoundly decreased the amylase and urease activity and enhanced the cellulase activity at doses recommended by the trader. Similar results were observed on the amylase and urease activity after Bravo 500 application. In addition, the cellulase and xylanase activities were increased by the both insecticides applied at recommended levels to control insect pests.
The stimulatory effect of tested pesticides could be attributed to the adaptive capabilities of soil microorganisms to minimize the negative influence of chemical stressors under adverse conditions. The enzymes could also be protected by clay fractions or humic substances $(0-20 \mathrm{~cm}$ depth) present in soil (Bagmaga, 2016).

Acknowledgments. This research did not receive any specific grant from funding agencies in the public, commercial, or not-for-profit sectors.

\section{REFERENCES}

1. Bending GD, Turner MK, Rayns F, Marx MC, Wood M (2004) Microbial and biochemical soil quality indicators and their potential for differentiating areas under contrasting agricultural management regimes. Soil Biol Biochem 36:1785-1792.

2. Chu HY, Zhu JG, Xie ZB, Zhang HY, Cao ZH, Li ZG (2003) Effects of lanthanum on dehydrogenase activity and carbon dioxide evolution in a Haplic Acrisol. Aust J Soil 43:731-739.

3. Cole MA (1977) Lead inhibition of enzyme synthesis in soil. Appl Environ Microbiol. 262-2688.

4. Defo MA, Njine T, Nola M, Beboua FS (2011) Microcosm study of the long term effect of endosulfan on enzyme and microbial activities on two agricultural soils of YaoundeCameroon. Afr JAgric Res 6:2039-2050.

5. Deng S, Tabatabai M (1994) Colorimetric determination of reducing sugars in soils. Soil BiolBiochem 26:473-477.

6. Gundi V, Viswanath B, Chandra MS, Kumar VN, Reddy BR (2007) Activities of cellulase and amylase in soils as influenced by insecticide interactions. Ecotox Environ Safe 68:278-285.

7. Ismail BS, Yapp KF, Omar O (1998) Effects of metsulfuronmethyl on amylase, urease, and protease activities in two soils, Australian Journal of Soil Research 36(3) 449 - 456.

8. Jastrzebska E (2011) The effect of chlorpyrifos and teflubenzuron on the enzymatic activity of soil. Pol J Environ Stud 20:903-910.

9. Lizy Sravanthi P, Madhuri T, Subramanyam D, Suvarnalatha Devi P (2015) Effect of cartap hydrochloride on amylase and cellulase enzyme activities in agricultural soil, International Journal of Life Sciences Vol. 4. No. 1, Pp. 44-47.

10. Madhuri JR and Venganampalle R (2014), Pesticidal effect on soil enzymes, International Journal of Chemical, Environmental \& Biological Sciences (IJCEBS) Volume 2, Issue 3.

11. Miller GL (1959) Use of dinitrosalicylic acid reagent for determination of reducing sugar. Analytical Chemistry. 31:426-429.

12. Monkiedje A, Spiteller M (2002) Effects of the phenylamide fungicides, mefenoxam and metalaxyl, on the microbiological properties of a sandy loam and a sandy clay soil. Biol Fertil Soils 35:393-398. 
13. Ramudu AC, Jaffer Mohiddin G, Srinivasulu M, Madakka $M$ and Rangaswamy V (2011) Impact of Fungicides Chlorothalonil and Propiconazole on Microbial Activities in Groundnut (Arachis hypogaea L.) Soils, ISRN Microbiol.

14. Tabatabai MA and Bremner JM (1969) Use of p-nitrophenyl phosphate for assay of soil phosphatase activity. Soil Biology and Biochemistry 1, 301-307.

15. Tabatai MA, Bremner JM (1972) Assay of urease activity in soil. Soil Biol Biochem 4: 479-487.

16. Tu CM (1982). Influence of pesticides on activities of invertase, amylase and levels of adenosine triphosphate in organic soil. Chemosphere 2, 909-914.

17. Yan H, Wang DD, Dong B, Tang FF, Wang BC, Fang H, Yu YL (2011) Dissipation of carbendazim and chloramphenicol alone and in combination and their effects on soil fungal: bacterial ratios and soil enzyme activities. Chemosphere 84:634-641.

18. Anuradha B, Jaffer Mohiddin. G, Rekhapadmini A and Rangaswamy V (2015) Interaction effects of selected pesticides on groundnut (Arachis hypogaea L.) soil enzymes, International Journal of Recent Scientific Research,Vol. 6, Issue, 2, pp.2801-2806.

19. Katayama A, Bhula R, Burns GR, Carazo E, Felsot A, Hamilton D, Harris C, Kim YH, Kleter G, Koedel W, Linders J, Peijnenburg JGMW, Sabljic A, Stephenson RG, Racke DK, Rubin B, Tanaka K, Unsworth J, Wauchope RD (2010) Bioavailability of xenobiotics in the soil environment. Rev Environ Contam Toxicol 203:1-86.

20. Baćmaga M, Boros E, Kucharski J, Wyszkowska J (2012), Enzymatic activity in soil contaminated with the Aurora 40 WG herbicide. Environ Prot Eng 38(1):91-102.

21. Baćmaga M, Wyszkowska J, Kucharski J (2016), The effect of the Falcon 460 EC fungicide on soil microbial communities, enzyme activities and plant growth, Ecotoxicology, 25:1575-1587.

22. Singh DK, Kumar S (2008) Nitrate reductase, arginine deaminase, urease and dehydrogenase activities in natural soil (ridges with forest) and in cotton soil after acetamipirid treatments. Chemosphere 71:412-418. 